'T'Urian, G. \& Cantino, E. C. (1959). J. gen. Microbiol. 21, 721-735

\title{
The Stimulatory Effect of Light on Nucleic Acid Synthesis in the Mould Blastocladiella emersonii
}

\author{
BY G. TURIAN \\ Department of Botany, University of Geneva, Sritzerland \\ AND E. C. CANTINO \\ Department of Botany, Michigan State University, East Lansing, Michigan, U.S.A.
}

\begin{abstract}
SUMMARY: The fungus Blastocladiella emersonii possesses neither chlorophyll nor coloured carotenoids; yet, visible light induces increased nuclear multiplication, increased synthesis of DNA relative to total nucleic acid, and detectable changes in the soluble phosphorus pool of the fungus. The stimulatory effect is detectable through ontogeny, from the first few hours after germination to the end of the generation time of $c .15$ to $25 \mathrm{hr}$. (depending on temperature). Light could be replaced by providing the plants with thymidine or thymine, but not with the corresponding RNA base, uracil. The DNA of $B$. emersonii contained the four principal bases usually associated with this nucleic acid. Finally, the interrelationships between DNA and RNA, and the effects thereon of nucleic acid analogues and inhibitors, were also studied. In particular, it was found that the DNA per cell doubled just before the first mitosis, while the total nucleic acid concentration did not change. The results of the latter experiments were interpreted in terms of the transformations which occur in the RNA-rich nuclear cap in the spores of the fungus during germination.
\end{abstract}

Upon germination, the spores of the water mould Blastocladiella emersonii may develop along three, distinctly different, ontogenetic paths (Cantino, 1959; Cantino \& Turian, 1959): one leads to the formation of brown, thickwalled, resistant sporangial plants (R.S. plants); a second leads to ordinary, thin-walled, colourless plants (O.C. plants); and a third leads to thin-walled, orange plants (O. plants). It has been established that visible light accelerates growth along all three developmental vectors (Cantino, 1957). The purpose of this paper is to provide further data about the stimulatory effect of light upon the thin-walled, colourless plants.

The O.C. plants of Blastocladiella emersonii possess no detectable amount of pigmented carotenoids or chlorophylls; in spite of this, they grow more rapidly in the light than in the dark, and they fix more $\mathrm{CO}_{2}$ per unit weight of organism under these conditions (Cantino \& Horenstein, 1956). Thus, from the point of view of both comparative biology and comparative biochemistry, $\boldsymbol{B}$. emersonii seems to occupy a unique position in the general scheme of living things.

Our previous studies, aimed at elucidating the mechanism of the stimulatory effects of light, were aimed along several different levels of integration. On the one hand, in vitro studies of $\mathrm{CO}_{2}$-fixation by liquid cultures involving several plant generations led to the notion that a s.K.I. (succinate-ketoglutarate-isocitrate) cycle was operative during light-stimulated growth and $\mathrm{CO}_{2}$ fixation whereby light, in some unknown fashion, mediated reductive 
carboxylation of ketoglutarate to isocitrate, the cleavage of isocitrate to. succinate and a $\mathrm{C}_{2}$ fragment, and perhaps the further conversion of part of the succinate back to ketoglutarate by a second reductive carboxylation. It was suggested that the $C_{2}$ piece (presumed to be glyoxylate) which resulted from cleavage of the isocitrate was involved in the increased proliferation induced by light. On the other hand, subsequent in vivo studies of the effect of light upon ontogeny led to the observations that the light effect was just as easily demonstrable when plants were grown for one generation only; parameters such as size of plants and time of discharge were directly related to the stimulatory effect of light (Cantino \& Horenstein, 1957). Then it was determined (Cantino \& Horenstein, 1959) that while the effect of light was completely dependent upon the presence of $\mathrm{CO}_{2}$ or bicarbonate, the light and bicarbonate could be replaced with an equimolar mixture of succinate and glyoxylate, the presumed products of the reductive carboxylation of isocitrate in the s.K.I. cycle mentioned above. This provided substantial in vivo corroboration for a mechanism that had been derived from a more generally biochemical approach. In addition, our most recent studies (H. McCurdy \& E. C. Cantino, to be published) have supplied new, direct evidence for the existence and role of the isocitritase and, even more pertinent here, a strong, pulling reaction subsequent to isocitritase; namely, a glyoxylate-alanine transaminase whose equilibrium lies in the direction of glycine and pyruvate and whose potential import for syntheses in general and light-stimulated growth in particular is obvious.

We had yet to establish, however-among other things-the exact locus for the light effect, the nature of the receptor, and the relationship between the formation of glyoxylate and glycine, on the one hand, and the biosynthetic reactions leading to increased synthesis of cytoplasmic and nuclear components, on the other. It was the purpose of this investigation to initiate an attack upon this latter, terminal area, and to determine if the light effect was reflected in demonstrable, intracellular changes during the very first few hours of ontogeny-that is, during spore germination and the subsequent formation of germlings.

\section{MATERIALS AND METHODS}

We have used the strain of Blastocladiella emersonii originally described by Cantino \& Hyatt (1953). The media employed were a peptone-yeast-glucose medium PYG (Cantino, 1952), now commercially available as Difco Cantino PYG broth and agar, and a diluted version (see context) of the synthetic medium of Barner \& Cantino (1952). Swarmer ('spore') suspensions were obtained by growing several thousand ordinary-colourless (O.C.) plants to maturity on PYG-agar, flooding the plates with sterile water when the population of first-generation plants was just beginning to discharge swarmers, and then collecting the swarmer suspension aseptically.

Nuclear counts were made on randomly selected germlings which were fixed with $10 \%$ formaldehyde and stained with $1: 10,000(\mathrm{w} / \mathrm{v})$ toluidine blue; whereby the nuclei are clearly delimited and easily counted with an 
oil-immersion objective by virtue of their deeply stained, blue-violet central body against the faintly blue background of the nucleoplasm (Turian \& Cantino, 1959). Spores were dried to constant temperature at $99^{\circ}$ for dryweight determinations. Ultraviolet absorption data were obtained in cells of $1 \mathrm{~cm}$. light path with a model DU Beckman spectrophotometer. For most studies, white light (fluorescent) was used at a level of 390 f.c.; for the work at $29^{\circ}$, however, it was about 300 f.c. Aminopterin and pteropterin were very kindly supplied by Dr J. M. Ruegsegger of the Lederle Laboratories. Purines and pyrimidines were obtained from Sigma Chemical Company.

The methods of McIntire \& Smith (1958), and McIntire \& Sproull (1957) were adopted, with slight modifications to suit our particular problem, for the routine determination of DNA and total purines and pyrimidines (TPP). Individual bases in nucleic acid hydrolysates were separated on unwashed Whatman paper no. 1 by chromatography with water + saturated butanol, isolated by elution and determined spectrophotometrically (Hotchkiss, 1948). Analyses for orthophosphate and total phosphorus were made essentially according to the Fiske-Subbarow procedure outlined by Umbreit, Burris \& Stauffer (1957). Total nitrogen was obtained by sulphuric acid digestions, subsequent nesslerization, and determinations with a Klett-Summerson colorimeter (cf. Umbreit et al. 1957).

\section{RESULTS}

In order to study the effect of light upon the initial stages of ontogeny, it was desirable to germinate simultaneously large quantities of spores and to synchronize subsequent development of the germlings for at least several hours. Actually, microscopic analyses of suspensions of germinating spores revealed that the degree of synchronization was already reasonably good without special treatments. However, attempts were made to improve it; the few positive results obtained are summarized below.

\section{Indoleacetic acid $(I A A)$}

This compound does affect the rate of spore germination, as it did in the close relative, Allomyces (Turian, 1956). When populations of spores were bathed in $2 \times 10^{-5} \mathrm{M}$-indoleacetic acid at $26^{\circ}$ for 30,45 and $60 \mathrm{~min}$. and then scored immediately for germination (along with untreated spores incubated for similar periods), it was found that indoleacetic acid did increase germination rates significantly, although the stimulatory effect decreased progressively with increased duration of treatment (Table 1). However, it did not improve the degree of synchronization over that of the control populations.

\section{Heat shocks}

Preliminary trials with different temperatures and time intervals revealed that a heat shock at $37^{\circ}$ did improve synchronization. For example, spores were treated at this temperature for 5, 15, 30 and $60 \mathrm{~min}$., they were then placed at $26^{\circ}$ for $6 \mathrm{hr}$., and at this point we tabulated for each population 
the frequency of thalli in each of three arbitrary classes: ungerminated spores, small germlings (2-4 nuclei), and large germlings (over 4 nuclei). Maximum synchronization occurred with a 15 min. heat shock (Table 2).

Table 1. Percentage increase in germination of spores induced by $2 \times 10^{-5} \mathrm{M}$ indoleacetic acid in $1 \%$ glucose solution at $26^{\circ}$

Spore populations were fixed with $5 \%$ formaldehyde and scored at the times indicated below; the criterion of germination was the formation of the first, detectable rhizoidal system.

$\begin{array}{cc}\begin{array}{c}\text { Duration of acid } \\ \text { treatment from }\end{array} & \begin{array}{c}\text { Percentage increase } \\ \text { over controls without } \\ \text { acro time (min.) }\end{array} \\ 30 & 44 \\ 45 & 34 \\ 60 & 23 \\ 90 & 7 \\ 120 & \text { c. } 0\end{array}$

Table 2. The effect of heat shocks upon synchronization of germination

Following the heat shocks, all populations were transferred to $26^{\circ}$ and scored after $6 \mathrm{hr}$. of incubation.

\begin{tabular}{|c|c|c|c|}
\hline $\begin{array}{c}\text { Duration of } \\
\text { initial heat } \\
\text { shock at } 37^{\circ} \\
\text { (min.) }\end{array}$ & $\begin{array}{c}\text { Percentage } \\
\text { motile and } \\
\text { resting, } \\
\text { non-germinated } \\
\text { spores }\end{array}$ & $\begin{array}{l}\text { Percentage } \\
\text { small } \\
\text { germlings } \\
(2-4 \text { nuclei })\end{array}$ & $\begin{array}{c}\text { Percentage } \\
\text { large } \\
\text { germlings } \\
\text { (over } 4 \text { nuclei) }\end{array}$ \\
\hline 0 & 6 & 15 & 79 \\
\hline 5 & 5 & 10 & 85 \\
\hline 15 & 3 & 6 & 91 \\
\hline 30 & 8 & 20 & 72 \\
\hline 60 & 21 & 38 & 41 \\
\hline
\end{tabular}

\section{The effect of light on nuclear reproduction}

Spores were germinated at $24^{\circ}$ in liquid medium PYG and incubated 2, 3 , 4, 5 and $6 \mathrm{hr}$. in the presence and absence of 390 f.c. of white light. The number of nuclei per plant was determined by direct, microscopic examination (Fig. 1). The number of nuclei per germling was decidedly greater in the light than in the dark for all incubation periods. Furthermore, when germlings incubated in light and dark were exposed simultaneously to thymidine and to uracil $\left(10^{-4}\right)$ : (a) uracil had no significant effect upon nuclear counts in either light or dark; $(b)$ thymidine had no effect upon nuclear counts in the light; but $(c)$ thymidine (and thymine) had a pronounced effect upon nuclear counts in the dark. Apparently, thymidine effectively stimulated nuclear multiplication to the same extent that light had done so! The progressive effect of light on the early ontogeny of Blastocladiella emersonii is clearly evident from the data in Fig. 2 in which we have averaged our total counts of nuclei in some hundreds of germlings grown for different times in light and dark. The inset in the figure delineates the clear-cut increase in nuclear reproduction brought about by light during the first $6 \mathrm{hr}$. of development. Finally, quite aside from the light effect itself, the abrupt change in slope of the curves at about $4 \mathrm{hr}$. is also worthy of note. 


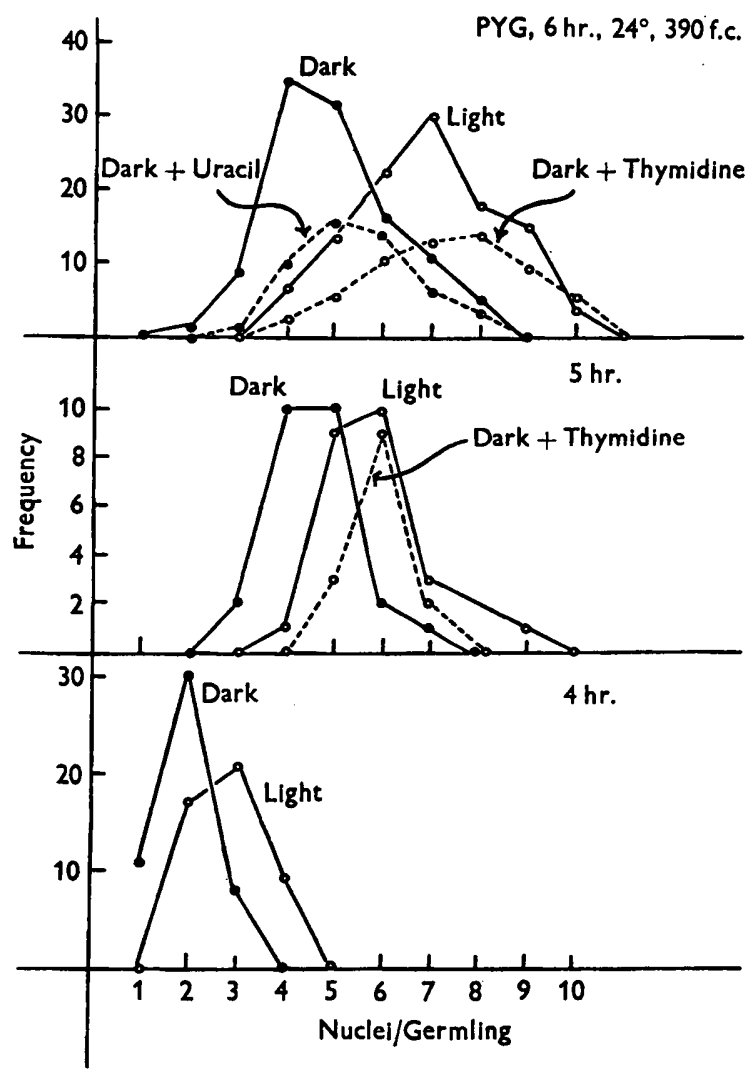

Fig. 1. The distribution curves for the number of nuclei found in young germlings grown for 6, 5 and $4 \mathrm{hr}$. on medium PYG at $24^{\circ}$ in the presence and absence of 390 f.c. of white light and with and without incorporation of uracil and thymine (and thymidine) in the medium. At these ages germlings were all of equal size.

\section{The effect of light upon nucleic acid synthesis}

The methods of McIntire \& Smith (1958), and McIntire \& Sproull (1957) were selected for the routine estimation of the total DNA and RNA content of germinating spores and germlings in our comparative studies because of their speed and simplicity. Actually, the estimation of RNA is based upon a measure of total purines and pyrimidines (TPP), on the one hand, and the isolation of DNA and its subsequent analysis in a separate fraction, on the other, the difference being referred to as RNA in our work. In effect, the RNA value is really a measure of RNA plus a small, soluble pool of purines and pyrimidines present in Blastocladiella emersonii.

In any event, the ratio of DNA to TPP (an approximate ratio of DNA to total nucleic acid) was determined during germination and growth of spores for one generation; the data revealed (Fig. 3) that this ratio was greater in light-grown plants of different ages than it was in comparable dark-grown plants. Thus, it seems as if DNA increases more rapidly than RNA in lightgrown plants than it does in dark-grown plants; this corresponds nicely with 
the observed increases in nuclear reproduction brought about by light during the early stages of germination and growth. In the close relative, Allomyces, the $\%$ DNA of total nucleic acids is also increased (c. $25 \%)$ by providing the sexual (gametophytic) generation of the fungus with thymine. This observation may have an important bearing on the discovery (Turian, 1958) that thymine induces increased differentiation of male sex organs in Allomyces (cf. Cantino \& Turian, 1959, for discussion).

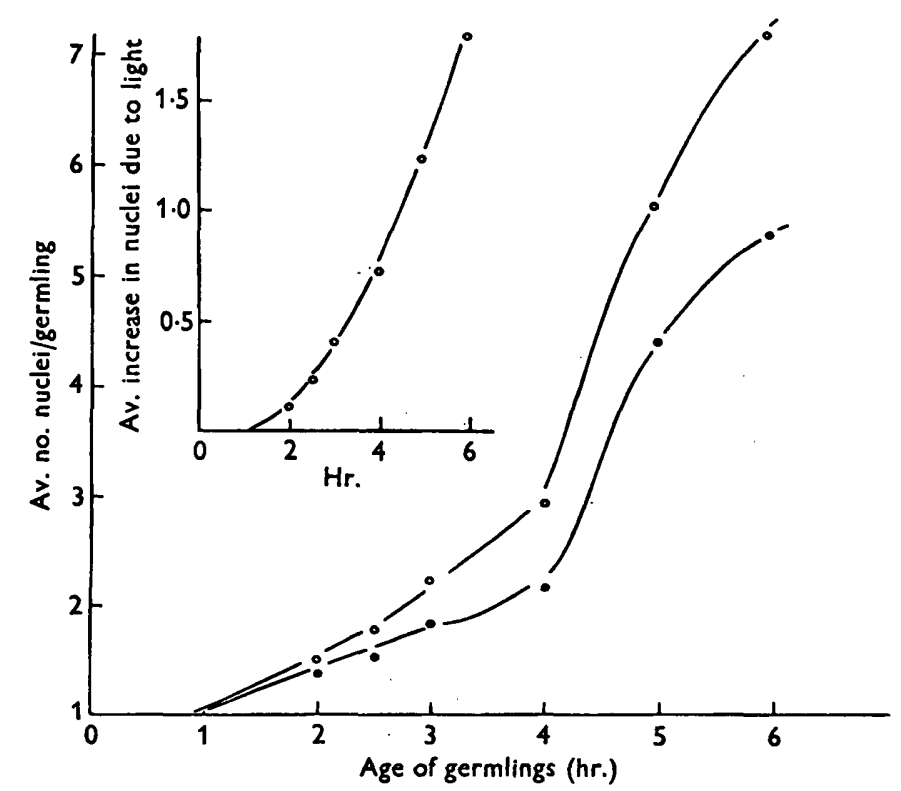

Fig. 2. The average number of nuclei in germlings grown for $2,3,4,5$ and $6 \mathrm{hr}$. on medium PYG at $24^{\circ}$ in the presence and absence of 390 f.c. of white light.

\section{The effect of analogues and inhibitors on nucleic acid synthesis}

Hoping that it would further help us to understand the nature of the changes brought about by light, the effects of a few, selected analogues and potential inhibitors of nucleic acid metabolism, were also tested. In this case, 1/20 strength medium PYG was used in order to reduce the concentration of nucleic acid components present in the yeast extract which might have functioned as antagonists for the analogues employed. The pertinent results were as follows: while bromouracil and pteropterin had only rather small effects upon the DNA/TPP ratio, isocytosine, thiouracil and aminopterin did induce a striking change; the latter three brought about 50-100\% increases in the DNA/TPP ratio (Table 3).

Finally, absolute values for DNA and RNA (defined as TPP less DNA) were related to one another per unit weight of spores during the germination. For this purpose, replicate samples of spore suspensions used for analyses were sacrificed for the dry-weight determinations. Depending upon the 
batch of spores used, the initial concentration of DNA in the ungerminated spores varied between 13 and $17 \mu \mathrm{g}$ DNA/mg. dry 'weight (average, 14.8); that of RNA varied between 190 and $270 \mu \mathrm{g} \mathrm{RNA} / \mathrm{mg}$. dry weight (average, 217). Once the young germlings were analysed, however, it became abundantly clear that during the early stages of spore germination, the increase in DNA/ TPP which occurred (Fig. 3) was due to a pronounced increase in DNA synthesis while the concentration of RNA per cell changed very little (Fig. 4).

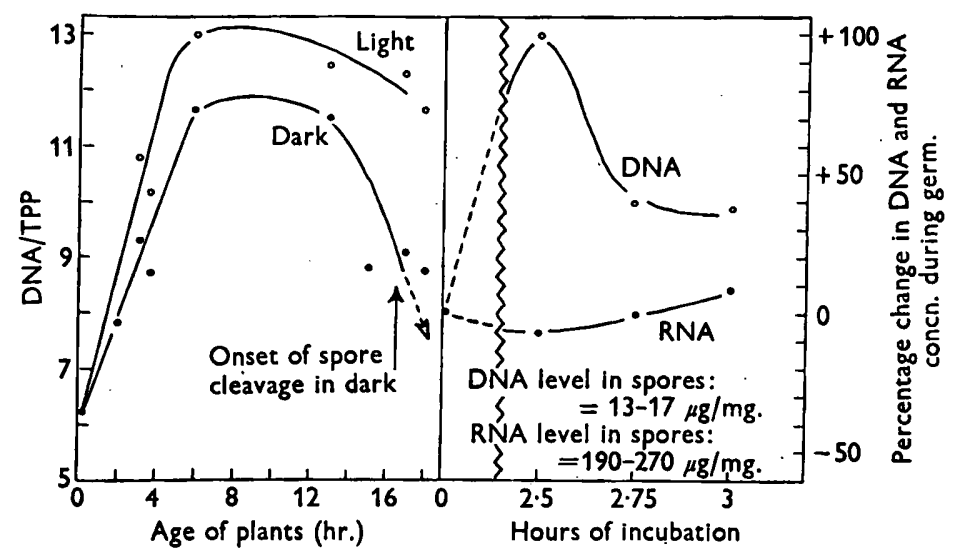

Fig. 3

Fig. 4

Fig. 3. The percentage DNA/TPP (total purines and pyrimidines) throughout ontogeny in light (390 f.c.) and dark. TPP in light and dark were the same.

Fig. 4. The percentage change in concentration of DNA and RNA in spores during a $3 \mathrm{hr}$. germination period in the dark. (The same relationship is obtained from pentose analyses, using orcinol (Umbreit, 1957), although absolute values average $20 \%$ low.)

Table 3. The effect of various compounds upon the $D N A / T P P$ ratio in germlings of Blastocladiella emersonii

Spores were germinated in medium PYG. 1/20 strength, in the presence and absence of $10^{-3} \mathrm{M}$ substrates for the times specified at $24^{\circ}$ in the dark. The data are expressed as percentage change of the DNA/TPP ratio from that of control cultures on the PYG medium lacking added substrates.

$\begin{array}{cccccc}\begin{array}{c}\text { Age of } \\ \text { germlings } \\ \text { at time of } \\ \text { analysis } \\ (\text { hr. })\end{array} & \text { Bromouracil } & \text { Thiouracil } & \text { Pteropterin } & \text { Isocytosine } & \text { Aminopterin } \\ & & \text { Corcentage change in the } & \text { DNA/TPP ratio } & \\ 5 & -2 & -8 & -8 & +80 & + \\ 6 & + & +105 & -18 & + & +95 \\ 7 & +20 & - & - & +57 & +75\end{array}$

The composition of the DNA in Blastocladiella emersonii

The DNA isolated from light- and dark-grown, synchronized cultures (14 hr. plants) by the salamine methods previously described was subjected to hydrolysis with $2 \cdot 4 \mathrm{~N}-\mathrm{HCl}$ for $2 \mathrm{hr}$. (in an autoclave at $120^{\circ}, 15 \mathrm{lb}$. pressure) 
and chromatographed in water-saturated butanol according to Hotchkiss (1948), along with authentic samples of the four principal DNA bases. The results (Fig. 5) revealed that: $(a)$ the DNA contained the expected bases thymine, adenine, and cytosine (and probably guanine, whose mobility is low in the solvent system used); (b) the DNA seemed to contain two, unidentified components which peak in the region of $260 \mathrm{~m} \mu$ (the possibility that they are simply incomplete-hydrolysis products has not been ruled out); and (c) no clearly significant differences between DNA from light-grown plants and DNA from dark-grown plants was detected, although the possibility remains that the ratio of the individual bases to one another may be affected by exposure of the plants to light. This possibility is to be pursued further.

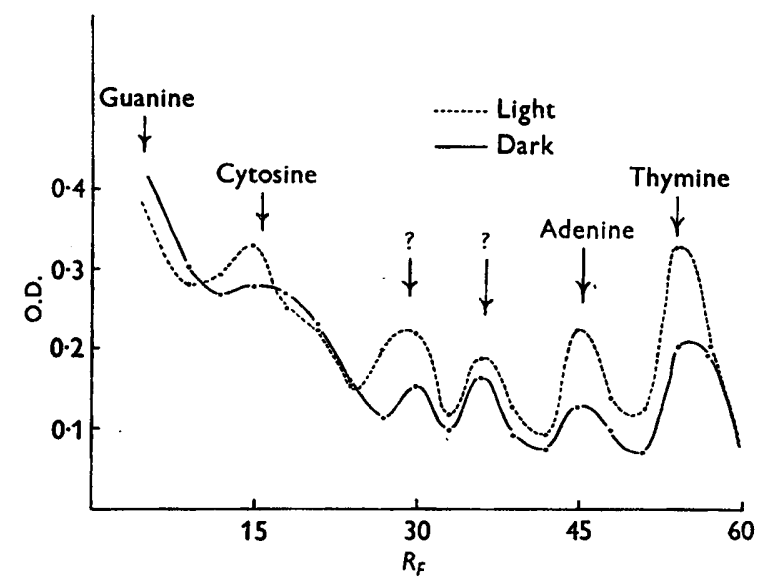

Fig. 5. The composition of $\mathrm{HCl}$ hydrolysates of DNA isolated from Blastocladiella emersonii as revealed by chromatography in water-saturated butanol according to Hotchkiss (1948) and measured at $260 \mathrm{~m} \mu$.

\section{The effect of light upon phosphorus metabolism during germination and early development of germlings}

On full-strength synthetic medium D (Barner \& Cantino, 1952; containing glucose, glutamate, methionine, phosphate, magnesium sulphate and thiamine), the growth of Blastocladiella emersonii is also stimulated by light (Cantino, unpublished). Similarly, on this same medium the stimulatory effect of light upon nuclear multiplication was also demonstrated during our current studies. In the following experiments, spores were germinated in 1/10 strength medium $D$ but with the glucose at $0.005 \%$.

Over the $4 \mathrm{hr}$. period during which spore germination and growth of germlings was followed, there was no net uptake of phosphate; indeed, there was apparently a net release, the orthophosphate pool increasing more in the light than in the dark (Fig. 6, top). On the other hand, the extractable (TCAsoluble) nitrogen pool increased much more rapidly in the light than in the dark (Fig. 6, centre). Thus, the relative pool of orthophosphate per unit of $\boldsymbol{T C A}$-soluble nitrogen actually decreased much more rapidly in the light than it 
did in the dark during the early stages of spore germination (Fig. 6, bottom). Furthermore, the absolute pool of total TCA-soluble phosphorus also decreased more rapidly in the light than it did in the dark (Fig. 7). Apparently, this light-stimulated decrease in the soluble organic phosphorus was due, in the main, to a sharp decrease in the barium-insoluble fraction (B.I.F.) and the barium-soluble-alcohol-insoluble (B.S.A.I.F.) fractions of the TCA-soluble phosphorus pool (Fig. 7).

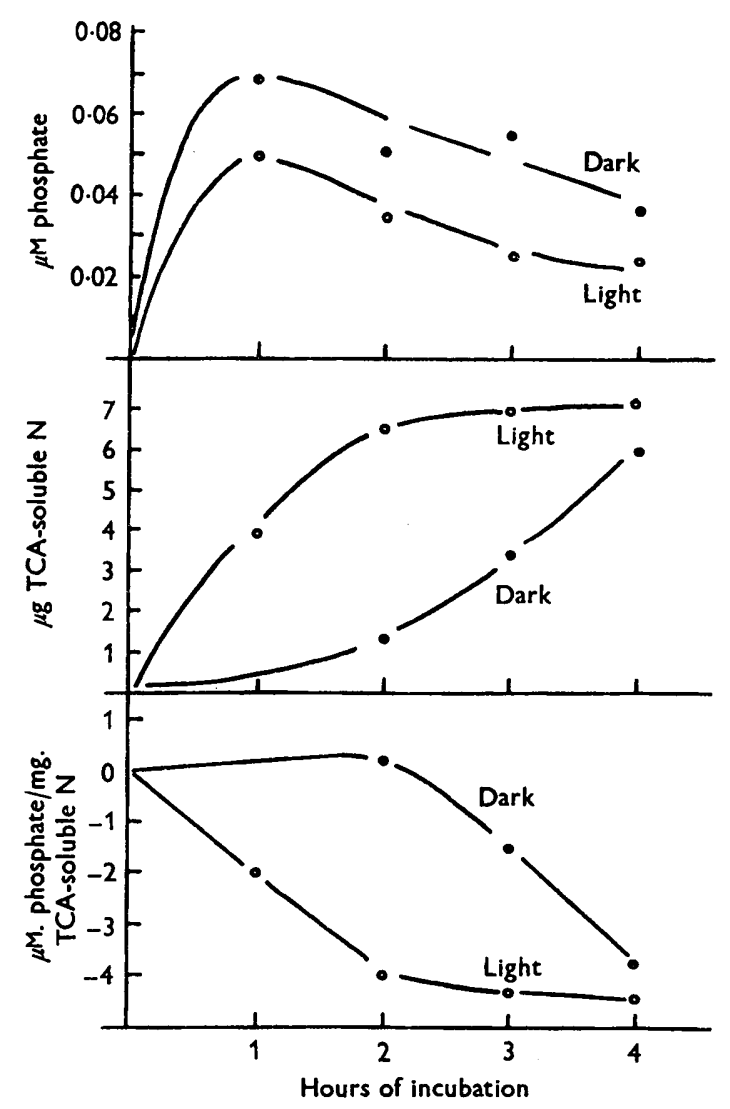

Fig. 6. Changes in the nitrogen and phosphorus pool in Blastocladiella emersonii during a $4 \mathrm{hr}$. germination period at $29^{\circ}$ in light (390 f.c.) and dark on $1 / 10$ strength medium $D$ containing $0.005 \%$ glucose. (Top): formation and re-utilization of orthophosphate; (centre): extractable TCA-soluble nitrogen; (bottom): the relative pool of orthophosphate per unit TCA-soluble nitrogen.

\section{DISCUSSION}

Gradually, a picture (but, admittedly, still a fuzzy one) of the stimulatory effect of light upon the growth of Blastocladiella emersonii is beginning to take shape. At this stage in the evolution of our perception of the situation, perhaps we can best visualize the picture as one with two focal points-a posterior and an 
anterior end, so to speak-connected by a thread of unknown magnitude and complexity (cf. Fig. 8).

At one end of this picture lies a block of reactions in which reductive carboxylation of ketoglutarate (via a TPN-specific isocitric dehydrogenase) provides the substrate for a subsequent reaction in the glyoxylate cycle (e.g.

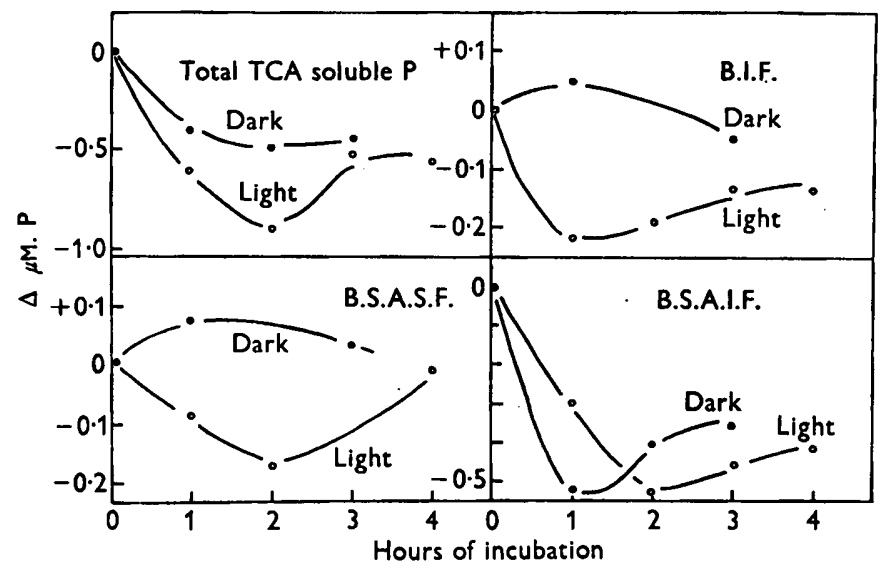

Fig. 7. Changes in the absolute pool of TCA-soluble phosphorus in Blastocladiella emersonii during a $4 \mathrm{hr}$. germination period at $29^{\circ}$ in light (390 f.c.) and dark on 1/10 strength medium D containing $0.005 \%$ glucose. (Upper left) : total TCA-soluble P; (upper right): barium-insoluble-fraction of the total TCA-soluble P; (lower left): barium-solublealcohol-insoluble fraction of the total TCA-soluble P; (lower right): barium-solublealcohol-soluble fraction of the total TCA-soluble $\mathbf{P}$.

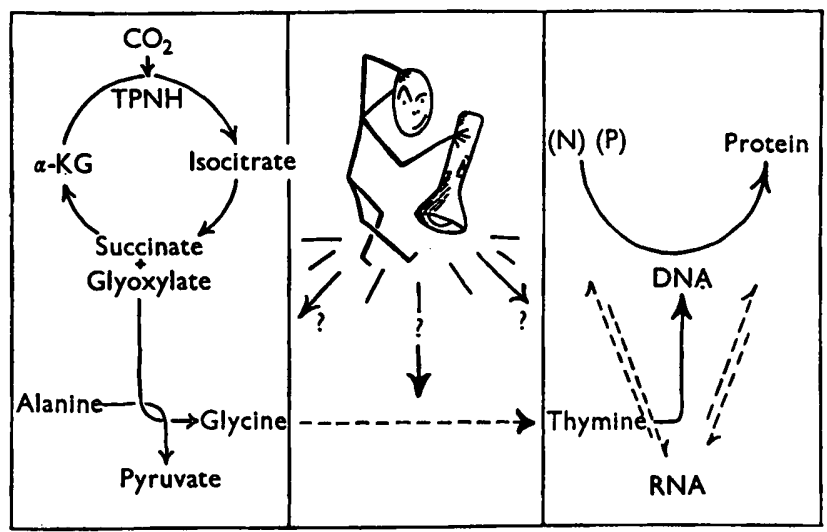

Fig. 8. Schematic digest of our current state of knowledge of light-stimulated growth in Blastocladiella emersonii (see text for explanation).

Kornberg \& Krebs, 1957)-namely, cleavage of isocitrate to succinate and glyoxylate (Cantino \& Horenstein, 1956, 1957, 1959; H. McCurdy \& E. C. Cantino, to be published). In Blastocladiella emersonii the equilibrium of a transamination between glyoxylate and alanine to yield pyruvate and glycine is such as to constitute a potentially strong, pulling reaction (H. McCurdy \& 
E. C. Cantino, to be published) for the isocitritase reaction and, therefore, for the reductive carboxylation of ketoglutarate (provided, of course, that reduced TPN is made available). Light increases the rate at which $\mathrm{CO}_{2}$ is fixed via ketoglutarate reduction. It is not at all clear how this effect of light is exerted-whether it 'pushes' the reaction by production of increased reducing power to drive the carboxylation, 'pulls' the reaction by accelerating some step subsequent to the carboxylation, or causes some other effect. But the fact remains that $\mathrm{CO}_{2}$ or bicarbonate is essential for the light effect, and that one can substitute for radiant energy the products of the reaction which it seems to accelerate-that is, an equimolar mixture of glyoxylate and succinate (Cantino \& Horenstein, 1959).

At the other end lies the second block of reactions, and this region of metabolism also proceeds in higher gear when light is present; the visible, end result is an accelerated rate of nuclear reproduction. (Judging from reports such as those of Ogata, Shimizu \& Togashi, 1958; Stegwee, 1955; Caspersson, 1950; Brachet, 1957, etc., this could mean increased rates of protein synthesis as well.) Furthermore, this light-stimulated increase in microscopically detectable nuclear synthesis is paralleled by a light-stimulated increase in the ratio of DNA to total nucleic acids as determined by chemical analysis. But here, too, the stimulatory effect of light can be replaced by supplementing the organism with a nutrient, in this case, thymine! Perhaps, then, biosynthesis of thymine is a natural, limiting factor in the growth of Blastocladiella emersonii, and supplementation of the thymine pool (by addition of thymine in the dark, or by a light-induced, increased synthesis) overcomes the barrier.

In any event, we are led to the interesting conclusion that either glyoxylate plus succinate, on the one hand, or thymine on the other, can substitute for light in stimulating growth. The literature dealing with the role of amino acids in nucleic acid synthesis is expanding rapidly; for glycine, in particular, the evidence suggests that it is involved in nucleic acid synthesis.(e.g. Crosbie, 1958; Sutton, Schlenk \& Werkman, 1951; Kritskii \& Myagkaya, 1956, and others). In view of the aforementioned presence of a strong glyoxylate-alanine transaminase in Blastocladiella emersonii (H. McCurdy \& E. C. Cantino, to be published) which leads to the formation of glycine, we have selected the working hypothesis that light, in some unknown fashion, accelerates the following chain of events: reductive carboxylation of ketoglutarate to yield isocitrate, cleavage of isocitrate to succinate and glyoxylate, transamination of glyoxylate with alanine to yield glycine, conversion of glycine to thymine, and, finally, metabolism of thymine to yield DNA and, therefore, increased protein synthesis and increased growth (Fig. 8).

Obviously, the principal hurdle to be overcome at the biochemical level is the nature of the link between the posterior and anterior ends of this pictureand at the biophysical level, the locus for the stimulatory effect of light and the mechanism of its action. But, whatever the nature of the final answer, this seems to be a unique phenomenon: that of a mould, without chlorophyll and without coloured carotenoids, which produces more nuclei and more DNA, fixes more $\mathrm{CO}_{2}$, and grows more rapidly in the light than in the dark! 
Apart from the photosensitivity of Blastocladiella emersonii, the nucleic acid transformations during spore germination deserve special attention. The blastocladiaceous spore is organized in intriguing fashion into intracellular compartments, one of the most obvious and most interesting being the RNArich nuclear cap (cf. Cantino \& Turian, 1959, for discussion). During germination, the latter disorganizes and eventually disappears. Our determinations of DNA and TPP during germination may provide an important clue for understanding the reciprocal relationship between nuclear DNA and paranuclear-nuclear RNA at this critical stage in ontogeny.

Our analytical data consistently revealed that the TPP (or approximately total nucleic acid) per cell remained essentially constant, from the zoospore stage to that of a young, $2 \frac{1}{2} \mathrm{hr}$. germling (Fig. 4). This steady level, however, implies a gradual decrease in nucleic acids per unit dry weight, for the latter increases between the first $1 \frac{1}{2}-3 \mathrm{hr}$. following germination as synthesis of proteins, chitin, etc. accompanies the enlargement of the cell and the growth of rhizoids. Simultaneously, however, the DNA content per cell doubles just before the outset of the first mitosis (as it does, for example, in bacteria; Barner \& Cohen, 1956) which occurs between 2 and $3 \mathrm{hr}$. after germination (Fig. 1). If, during this time, the total nucleic acid is constant, as it seems to be, one can hardly escape the conclusion that the sudden increase in DNA occurs at the expense of the total pool of TPP, as illustrated in Table 4.

Table 4. Change in absolute value of nucleic acid components during germination, expressed in $\mu \mathrm{g} / 10^{6}$ cells (spores or germlings)

$\begin{array}{lccc} & \text { TPP } & \text { DNA } & \text { 'RNA'* } \\ \text { Spores } & 403 & 28 & 375 \\ 2 \frac{1}{2} \text { hr. germlings } & 408 & 53 & 355 \\ \text { Change } & +5 & +25 & -20\end{array}$

* 'RNA' equals RNA plus the pool of nucleotides, nucleosides, purines and pyrimidines.

Moreover, the fact that this nucleic acid pool is probably concentrated in the main, in the RNA nuclear cap at the swarmer (zoospore) stage (Turian, 1955) suggests a function for this cytoplasmic body found in the Blastocladiaceae. Its essential role during germination, when it disintegrates and donates its basophilic constituents to the cytoplasm, would be associated not only with resumption of protein synthesis (Turian, 1956) but also with its capacity to serve as a reservoir of nucleic acid building blocks for the sudden synthesis of DNA in the nucleus. Thus, the doubling of the DNA which precedes the first mitosis corresponds to a sort of 'partial synthesis' of DNA from preexisting nucleic acid precursors such as the nucleosides and nucleotides made available during the disintegration of the nuclear cap during germination.

Such a 'partial synthesis' of DNA from a pre-existing pool of nucleic acids and their building blocks is consistent with our earlier data (Turian, 1958) concerning: $(a)$ the absence of dinitrophenol toxicity during the first stages of germination (up to the $\mathbf{3} \mathrm{hr}$. binucleate germling stage) in Allomyces; and (b) the strong, inhibitory effect of dinitrophenol upon further growth of germ- 
lings of Allomyces in which total synthesis of nucleic acids is subsequently presumed to occur (and, in Blastocladiella emersonii, does occur; see Fig. 3).

In this connexion, one last thought: it is axiomatic that parallel synthesis of both DNA and RNA must proceed during the development of young germlings into mature plants; presumably, this occurs at a steady state if the ratio of the two components is to be maintained at a temporarily constant level (Fig. 3). But, in diametric opposition to the situation that occurs during germination, it must be assumed that DNA synthesis stops earlier than RNA synthesis during ontogeny if the ratio of DNA/TPP is to decrease ultimately to $c .6 \%$ when the mature plant once again undergoes progressive cleavage into swarmers containing the RNA-rich, nuclear caps.

Finally, the use of compounds antagonistic to nucleic acid metabolism has provided additional clues for an understanding of nucleic acid synthesis during germination in Blastocladiella emersonii. It was to be expected that analogues such as thiouracil and isocytosine would inhibit RNA synthesis (which is resumed some $3 \mathrm{hr}$. following germination; see Fig. 4) and thus increase the DNA/TPP ratio in $B$. emersonii. This was in fact the case, although thiouracil was effective only at rather high concentrations; at $2 \times 10^{-4} \mathrm{M}$, it did not modify the DNA/TPP ratio. On the other hand, 5-bromouracil behaved more or less like thymine, and this was perhaps not unexpected in view of the substitution of this analogue for thymine in bacterial DNA (e.g. Zamenhof, Rich \& de Giovanni, 1958; Cohen \& Barner, 1956; Dunn \& Smith, 1957).

With folic acid analogues, however, the results were particularly interesting, and somewhat unexpected. Pteropterin, a rather soluble compound, induced a decrease in the $\mathrm{DNA} /{ }^{\prime} \mathrm{RNA}$ ' ratio, presumably through a selectively inhibitory effect on DNA synthesis, at concentrations which did not inhibit growth. On the contrary, aminopterin (less soluble and more toxic) produced surprisingly high ratios, especially at growth-reducing concentrations. This was accompanied by striking cytological effects: elongated germlings with low basophily and only one or at most two or three giant nuclei (and nucleoli) in cytoplasmic compartments with space for six to eight normal-sized nuclei (cf. Nickerson \& Mankowski, 1953; and Nickerson \& Webb, 1956, for induced filamentation in Candida and Bacillus cereus by aminopterin). One explanation for the increased ratio, reinforced by the above cytopathological effects, would be that partial DNA synthesis from the nucleic acid pool is unaffected, and even proceeds faster than normal, while further nucleic acid synthesis from smaller building blocks is sharply inhibited. In this sense, then, the aminopterin effect would provide indirect confirmation of the notion that conversion of TPP to DNA is associated with the function of the nuclear cap as a reservoir of nucleic acids.

This work was supported by research grants from the Eli Lilly Company, Indianapolis, the National Science Foundation (Grant NSF-G-7493) and the National Institutes of Health (Grant E-1568 (c2)).

Paper no. 59-21 from the Department of Botany and Plant Pathology, Michigan State University, East Lansing, Mich., U.S.A. 


\section{REFERENCES}

Barner; H. D. \& Cantino, E. C. (1952). Nutritional relationships in a new species of Blastocladiella. Amer. J. Bot. 39, 746.

Barner, H. D. \& Cohen, S. S. (1956). Synchronization of division of a thymineless mutant of Escherichia coli. J. Bact. 72, 115.

Brachet, J. (1957). Biochemical Cytology. New York: Academic Press.

Cantino, E. C. (1952). The biochemical nature of morphogenetic patterns in Blastocladiella. Amer. Nat. 86, 379.

Cantino, E. C. (1957). Light-stimulated growth and $\mathrm{CO}_{2}$ fixation in a chlorophyll-less fungus, Blastocladiella. Proc. 2nd Int. Congr. Photobiol. p. 453.

Cantino, E. C: (1959). Relations of metabolism to cell development. Handb. Pflanzenphysiologie, vol. 15. Heidelberg, Germany: Springer Verlag.

Cantino, E. C. \& Horenstein, E. A. (1956). The stimulatory effect of light upon growth and $\mathrm{CO}_{2}$ fixation in Blastocladiella. I. The S.K.I. cycle. Mycologia, 48, 777 .

Cantino, E. C: \& Horenstein; E. A. (1957). The stimulatory effect of light upon growth and $\mathrm{CO}_{2}$ fixation in Blastocladiella. II. Mechanism at an organismal level of integration. Mycologia, 49, 892 .

Cantino, E. C. \& Horenstein, E. A. (1959). The stimulatory effect of light upon growth and $\mathrm{CO}_{2}$ fixation in Blastocladiella. III. Further studies in vivo and in vitro. Physiol. Plant. 12, 251.

Caintino, E. C. \& Hyatt, M. T. (1953). Phenotypic 'sex' determination in the life history of a new species of Blastocladiella, B. emersonii. Leeurvenhoek ned. Tijdschr. 19, 25.

Cantino, E. C. \& Turian, G. F. (1959). Physiology and development of lower fungi (Phycomycetes). Annu. Rev. Microbiol. 13, 97.

Caspersson, T. (1950). Cell Grozth and Cell Function. New York: W. W. Norton and Co., Inc.

Cohen, S. S. \& BARNer, H. D. (1956). Studies on the induction of thymine deficiency and on the effect of thymine and thymidine analogues in Escherichia coli. J. Bact. 71, 588.

Crosbie, G. W. (1958). Pyrimidine biosynthesis in Escherichia coli. Biochem. J. 69,1 .

Dunn, D. B. \& Smith, J. D. (1957). Effects of 5-halogenated uracils on the growth of Escherichia coli and their incorporation into desoxyribonucleic acids. Biochem. J. 67, 494.

Hотснкіss, R. D. (1948). The quantitative separation of purines, pyrimidines, and nucleosides by paper chromatography. J. biol. Chem. 175, 315.

KornberG, H. L. \& KreBs, H. A. (1957). Synthesis of cell constituents from $\mathrm{C}_{2}$ units by a modified tricarboxylic acid cycle. Nature, Lond. 179, 988.

Kritskir, G. A. \& Myagkaya, G. L. (1956). Metabolism of glycine and synthesis of purines in pigeon liver. C.R. Acad. Sci. U.R.S.S. 111, 398.

McInTIRe, F. C. \& SMITH, M. F. (1958). A new chemical method for measuring cell populations in tissue cultures. Proc. Soc. exp. Biol., N.Y. 98, 76.

McIntire, F. C. \& Sproull, M. F. (1957). A simple method for determination of desoxypentose nucleic acid in tissue culture. Proc. Soc. exp. Biol., N.Y. 95, 485.

Nickerson, W. J. \& MANKowski, Z. (1953). Role of nutrition in the maintenance of the yeast shape in Candida. Amer. J. Bot. 40, 584.

Nickerson, W. J. \& WebB, M. (1956). Effect of folic acid analogues on growth and cell division of non-exacting microorganisms. $J$. Bact. 71, 129.

Ogata, K., Shimizu, T. \& Togashi, K. (1958). Dependence of the uptake of glycine labelled with carbon 14 by protein fractions on ribonucleic acid (RNA) biosynthesis in slices of regenerating rat liver. Biochim. biophys. Acta, 29, 656. 
Stegwee, D. (1955). Some aspects of purine metabolism in mutants of Ophiostoma multiannulatum (Hegc. and Davids) v. Arx. Acta bot. neerl. 4, 575.

Sutton, W. B., Schlenk, F. \& Werkman, C. H. (1951). Glycine as a precursor of bacterial purines. Arch. Biochim. biophys. 32, 85.

Turian, G. F. (1955). Sur la nature ribonucléique du corps paranucléaire et ses relations avec la différenciation du sexe chez Allomyces javanicus. C.R. Acad. Sci., Paris, 240, 2343.

Turian, G. F. (1956). Activation concomitante par l'hétéroauxine de la résorption du corps paranucléaire ribonucléique et de la germination des zygotes chez Allomyces. Experientia, 12, 24.

Turian, G. F. (1958). Recherches sur les bases cytochimiques et cytophysiologiques de la morphogenèse chez le champignon aquatique Allomyces. Rev. Cytol. Biol. vég. 19, 2411.

Turian, G. F. \& Cantino, E. C. (1959). A study of mitosis in the mold Blastocladiella with a ribonuclease-aceto-orcein staining technique. Cytologia, 24. To be published.

Umbreit, W. W., Burris, R. H. \& Stauffer, J. F. (1957). Manometric Techniques and Related Methods for the Study of Tissue Metabolism. Minneapolis: Minn. Burgess Publ. Co.

Zameniof, S., Rich, K. \& DE Giovanni, R. (1958). Further studies on the introduction of pyrimidines into desoxyribonucleic acids of Escherichia coli. J. biol. Chem. 232, 651.

(Received 9 June 1959) 